\title{
Experimental dissolution of a fossil foraminiferal assemblage (Paleocene-Eocene Thermal Maximum, Dababiya, Egypt): Implications for paleoenvironmental reconstructions
}

\author{
Thi Minh Phuong Nguyen ${ }^{\mathrm{a}, *}$, Maria Rose Petrizzo ${ }^{\mathrm{b}}$, Robert P. Speijer ${ }^{\mathrm{a}}$ \\ a Department of Earth and Environmental Sciences, K.U.Leuven, Celestijnenlaan 200E, 3001 Leuven, Belgium \\ b Università degli Studi di Milano, Dipartimento di Scienze della Terra, “Ardito Desio”, via Mangiagalli 34, 20133 Milano, Italy
}

\section{A R T I C L E I N F O}

\section{Article history:}

Received 7 July 2009

Received in revised form 22 September 2009

Accepted 1 October 2009

\section{Keywords:}

Dissolution

Benthic foraminifera

Planktic foraminifera

Dababiya

Paleocene-Eocene

Paleoenvironment

Taphonomy

\begin{abstract}
A B S T R A C T
Dissolution experiments were carried out on a foraminiferal assemblage from the Paleocene-Eocene Thermal Maximum (PETM) at Dababiya, Egypt, in order to: 1) reveal the effects of differential dissolution on the composition of the foraminiferal assemblage and 2) develop objective criteria for the evaluation of dissolution in foraminiferal assemblages used in early Paleogene paleoenvironmental reconstructions, particularly with respect to neritic Midway-type assemblages from the Paleocene/Eocene transition. Our results confirm two general observations on modern foraminifera: 1) planktic foraminifera are much more vulnerable to dissolution than benthic foraminifera, leading to depressed P/B ratios and 2) dissolution susceptibility differs between size fractions, with the smaller specimens dissolving more rapidly than the bigger ones, leading to a larger average size of the remaining assemblage. Within a size fraction, wall structure and thickness are considered to be the main factors controlling differential dissolution susceptibility. We propose a ranking scheme for taxa with respect to dissolution resistance. Among the benthic taxa, Lenticulina is most resistant, followed by the agglutinated Gaudryina cf. ellisorae and Alabamina midwayensis. Biserial and triserial hyaline taxa and the porcelaneous Spiroloculina sp. are most susceptible to dissolution, whereas rotaliines, such as Cibicidoides and Anomalinoides have an intermediate susceptibility. This implies that mild dissolution of a Midway-type benthic assemblage leads to a relative enrichment in Lenticulina, Gaudryina and rotaliines. Amongst planktic foraminifera, the muricate taxa Acarinina and Morozovella are most resistant, followed by the cancellate Subbotina. The smooth and generally small Globanomalina and Zeauvigerina are least resistant to dissolution. Our data enable to objectively evaluate various degrees of dissolution in benthic and planktic foraminiferal assemblages retrieved from the lower Paleogene Tethyan outcrops. In this way taphonomic artifacts can be readily distinguished from paleoenvironmental signals affecting the primary composition of the assemblages. More generally, we propose that the combined use of foraminiferal numbers, $\mathrm{P} / \mathrm{B}$ ratio and relative abundances of non-calcareous agglutinated taxa and Lenticulina may provide a powerful proxy for assessing dissolution in hemipelagic assemblages from Cenozoic and upper Cretaceous continental margins. In order to achieve more robust pre-Quaternary paleoenvironmental reconstructions based on quantitative foraminiferal data, application of dissolution proxies, like proposed here, or in slightly modified form, should become a more widely used micropaleontologic procedure. Particularly continental margin studies dealing with major biotic events (e.g. PETM) or employing P/B ratios for sea-level reconstructions should benefit from such an approach.
\end{abstract}

(c) 2009 Elsevier B.V. All rights reserved.

\section{Introduction}

Fossil foraminifera provide a prime tool in marine paleoenvironmental reconstructions. Their shells record physico-chemical conditions in the water column and on the sea floor, which through geochemical analyses are being employed in paleoclimatic, paleocea-

\footnotetext{
* Corresponding author. Tel.: +32 16 326452; fax: +32 16322980.

E-mail address: thiminhphuong.nguyen@ees.kuleuven.be (T.M.P. Nguyen).
}

nographic and stratigraphic research. The basic assumption in paleoenvironmental reconstructions is that fossil assemblages truthfully mirror the original biocoenosis and underlying environmental signals (e.g. van der Zwaan et al., 1990 ). However, fossil communities and assemblages contain time-averaged signals, which actually could mainly be driven by contrasts in (temporary) environmental variations (Martin and Liddell, 1991; Martin, 1993). Taphonomic factors, especially selective dissolution, can severely alter the composition of fossil foraminiferal assemblages (e.g. Berger, 1970; Thunell and Honjo, 1981; Martin and Wright, 1988; Le and Thunell, 1996; Speijer 